\title{
Hepatitis C. A challenge to hepatologists and to the liver transplantation team ${ }^{1}$
}

\author{
Hepatite C. Um desafio aos hepatologistas e à equipe de transplante de fígado
}

\author{
Ana de Lourdes Candolo Martinelli'; Andreza Correa Teixeira ${ }^{3}$; Fernanda Fernandes Souza ${ }^{3}$; Ajith Kumar \\ Sankarankutty ${ }^{4}$; Orlando de Castro e Silva ${ }^{5}$
}

1. Study performed in the Division of Gastroenterology of the Department of Medicine and in Liver Transplantation Unit of the Division of Gastroenterology of the Department of Surgery and Anatomy of Ribeirão Preto Faculty of Medicine - University of São Paulo (FMRP-USP), Brazil.

2. PhD, Professor of the Department of Medicine, (FMRP-USP), Brazil.

3. Fellow Master degree, Member of the Liver Transplant Program of the Division of Gastroenterology of Department of Surgery and Anatomy, (FMRP-USP), Brazil.

4. PhD, Professor of the Department of Surgery and Anatomy, Division of Gastroenterology. Operational coordinator of the Liver Transplant Program, (FMRP-USP), Brazil.

5. Full Professor, Head of Division of Gastroenterology of the Department of Surgery and Anatomy, Coordinator of the Liver Transplant Program, (FMRP-USP), Brazil.

\begin{abstract}
Hepatitis $\mathrm{C}$ is the main cause of cirrhosis and hepatocellular carcinoma and the leading indication of liver transplantation. The aim of this article was to review specific epidemiological, clinical and therapeutic aspects of hepatitis $\mathrm{C}$ and theirs implication for the hepatologists belonging to liver transplantation services. These specific aspects were reviewed in the literature mainly using Medline. Data regarding the epidemiological, clinical and therapeutic aspects of hepatitis $\mathrm{C}$ are discussed, with emphasis on their consequences for the liver transplantation team. Hepatitis $\mathrm{C}$ is a challenge for hepatologists and for the liver transplantation team. The burden we observe today is the late consequence of infection that occurred in the past. Measures for early recognition of complications of liver disease are recommended. HCV treatment should always be performed before liver transplantation if possible, but if not, HCV recurrence should be recognized and treated early after transplantation.
\end{abstract}

Key words: Hepatitis C Complications. Liver Transplantation. Burden. Hepatitis C Reinfection.

\section{RESUMO}

O objetivo deste artigo foi revisar aspectos epidemiológicos, clínicos e terapêuticos da hepatite C e suas implicações para a equipe de transplante de fígado. Esses aspectos específicos foram revisados na literatura usando principalmente o Medline.Dados relativos a aspectos epidemiológicos, clínicos e terapêuticos da hepatite $\mathrm{C}$ foram discutidos com ênfase nas suas conseqüências para a equipe de transplante de fígado. A hepatite $\mathrm{C}$ é um desafio para hepatologistas e para a equipe de transplante de fígado. A epidemia que observamos atualmente é a conseqüência tardia da infecção que ocorreu no passado. São recomendadas medidas para o reconhecimento precoce das complicações da infecção. Recomenda-se que o tratamento da hepatite $\mathrm{C}$ deve ser feito sempre que possível e de preferência, antes do transplante, mas se isso não for possível, esforços devem ser feitos para o reconhecimento precoce da reinfecção e instituição do tratamento.

Descritores: Hepatite C. Transplante Hepático. Epidemia. Hepatite C Reinfecção.

\section{Introdução}

Hepatitis $\mathrm{C}$ virus (HCV) is a small-enveloped RNA virus belonging to the Flaviviridae family ${ }^{1,2}$. HCV was identified in $1989^{1,2}$ and it is estimated to infect 170 million people worldwide (WHO). HCV infection frequently results in chronicity. After acute infection most cases develop chronic infection and may progress to a severe form of liver disease. It is estimated that $15-30 \%$ of $\mathrm{HCV}$ chronic hepatitis may progress to cirrhosis within years to decades after infection and $3-4 \%$ of them will develop hepatocellular carcinoma ${ }^{3}$. HCV shows remarkable sequence variation. More than 90 subtypes have been identified around the world ${ }^{4}$. Phylogenetic analysis of full-length or partial sequences of
$\mathrm{HCV}$ has led to the identification of the 6 main genotypes numbered 1-6 and a large number of subtypes groups identified by lower case letters $(a, b, c)^{2}$. HCV also exists as a pool of genetically distinct but closely related variants referred to as quasispecies ${ }^{5}$. The prevalence of different genotypes varies according to geographic region. The most prevalent HCV genotypes are 1a, 1b, 2a, 2b, 2c, 3a and $4 a^{6}$. Genotype $1 \mathrm{~b}$ was mainly transmitted by blood transfusion before blood screening for HCV became available whereas genotypes $1 \mathrm{~b}$ and $3 \mathrm{a}$ were transmitted by intravenous drug use. However, in industrialized countries the proportion of genotypes 1a and $3 \mathrm{a}$ have been increasing in relation to genotype $1 \mathrm{~b}$ since today intravenous drug is the main route of HCV transmission ${ }^{6}$. In Brazil, genotype 1 is the most 
frequent followed by genotype $3^{7}$. The genetic variability of $\mathrm{HCV}$ has been shown to have important clinical consequences. Viral genotype is a strong and independent predictor of the sustained virologic response to treatment. The major viral factors associated with impaired response are genotype 1 and high viral load ${ }^{8}$. The prevalence of $\mathrm{HCV}$ infection is variable in different geographic regions and may range from $0.6 \%$ to $22 \%{ }^{9}$. The highest prevalence is in Asia and Africa and the lowest in industrialized countries. In Brazil the prevalence varies among different regions. Population-based studies showed rates of $\mathrm{HCV}$ infection of $1.42 \%{ }^{10}$ in São Paulo (Southeast of Brazil). At the Blood Center of Ribeirão Preto (Southeast of Brazil) $1.2 \%$ of 25,891 blood donors (1996-2001) were positive for serum HCV antibodies in initial screening tests ${ }^{11}$. Hepatitis $\mathrm{C}$ infection is one of the 10 leading causes of death due to infectious disease worldwide ${ }^{9}$. It is estimated to cause 476,000 deaths per year due to complications of end-stage liver disease. In the US about 4 million people were infected with $\mathrm{HCV}, 2.7$ million of them have progressed to chronic infection. HCV causes 10,000 deaths per year in the US ${ }^{12}$. After World War II there was an increasing use of blood and blood products and of the intravenous route for drug injection. Post-transfusion non A non B hepatitis has been diagnosed since 1970 but only after identifying HCV in 1989 was it possible to recognize this virus as the most important cause of post-transfusion hepatitis. Thus, HCV has infected tens of millions of people worldwide by this route. After the introduction of the blood screening tests for HCV infection the number of post transfusion $\mathrm{HCV}$ infection decreased significantly. Currently the dominant form of HCV infection in industrialized countries is intravenous drug use. In developing countries unsterile medical procedures remain an important source. In Egypt several subjects were infected in a nationwide campaign for schistosomiasis treatment ${ }^{13}$. In Brazil we have seen several patients who were contaminated by intravenous injection of licit drugs with non discharged material. Although the incidence of $\mathrm{HCV}$ is decreasing, at least in some parts of world (Europe and US), it is still high. The WHO estimates that 3-4 million new infections are occurring per year worldwide with 30,000 cases/year in the US (CDC). The asymptomatic behaviour of HCV infection in most cases makes it more difficult to estimate and to control the disease. On the other hand the prevalence of $\mathrm{HCV}$ will not decrease until $2010^{12}$, due to the long time between infection and clinical manifestation of advanced liver disease. This time is usually estimated as several years; however, it can be reduced depending on genetic and environmental factors ${ }^{14}$. It is estimated that $\mathrm{HCV}$ will be responsible for increasing the cases of cirrhosis and hepatocellular carcinoma by two thirds compared to current data. The implications of these estimates are a source of concern and debate for liver transplantation services. The control of the infection with vaccines is still a challenge. Trials testing vaccines for $\mathrm{HCV}$ are in course ${ }^{15}$. There are many difficulties because HCV does not stimulate a strong immune response, its genomic variability is high and no small animal model is available. A significant progress regarding the treatment of $\mathrm{HCV}$ has been made in the last years, but treatment is still not ideal. The high costs associated with common side effects are limiting factors.
The current therapy for HCV is based on two drugs, interferon and ribavirin. Pegylated interferon was recently developed, showing a longer half-life, better pharmacokinetics and enhanced biological activity compared to standard interferon. However, the rate of sustained virologic response with pegylated interferon and ribavirin is around $50 \%{ }^{16,17}$, meaning that $50 \%$ of treated patients continue to have $\mathrm{HCV}$ infection after treatment. The treatment of $\mathrm{HCV}$ infection is an important tool for controlling the infection and it is the only way to avoid progression to more advanced liver disease. Due to the less than ideal rate of response with available drugs, new drugs or treatment schemes are needed for patients who do not respond to the usual regimen of interferon and ribavirin.

\section{HCV and hepatocellular carcinoma (HCC)}

The incidence of HCC is increasing as a result of the spreading of HCV. The treatment of choice for patients with HCC and cirrhosis is still liver transplantation. The survival rate is $75 \%$ in 4 years when the criteria to indicate transplantation are 1 nodule smaller than $5 \mathrm{~cm}$ or up to 3 nodules all smaller than $3 \mathrm{~cm}$ each ${ }^{18}$. Screening protocols for the early detection of HCC are recommended by using ultrasound and the serum alpha-fetoprotein test in high risk patients ${ }^{19}$. The major concern about the diagnosis of HCC is the waiting list time for transplantation, which allow the progression of the disease and impair the prognosis. In US the introduction of an arbitrary value for HCC in the MELD resulted in an increased number of transplanted patients. In the first year the number of transplanted patients for HCC increased from $7 \%$ to $22 \%$ and the waiting time on the list decreased from 2.3 years to 0.69 years ${ }^{20,21}$. Since MELD criteria were only recently introduced in Brazil, patients with HCC have received palliative treatment with ethanol injection or chemoembolization while on the waiting list. New perspectives are expected with the adoption of MELD criteria for listing patients.

\section{HCV and liver transplantation}

$\mathrm{HCV}$ infection is the main cause of cirrhosis and the leading diagnosis for end-stage liver disease in liver transplantation candidates in Europe and the US. HCV reinfection post liver transplantation evaluated by $\mathrm{HCV}$ RNA detection using the polymerase chain reaction occurs almost universally ${ }^{22}$. The natural history of the infection is modified by the transplantation with rates of cirrhosis recurrence of $8-44 \%$ in $5-7$ years ${ }^{23}$. Studies have suggested intra-operative re-infection of the liver graft at time of reperfusion ${ }^{24}$. There is a high probability that the source is the blood itself ${ }^{25}$. The viral load can return to the pre transplant values within 4 days after transplantation and may be influenced by the intraoperative or peroperative use of corticosteroids. Despite the early re-infection, the graft injury occurs only after 3 weeks ${ }^{26}$. Acute hepatitis occurs between 2-5 months post transplant and it is characterized by acute lobular hepatitis. A higher viral load and cellular immune response and a higher rate of cell proliferation and apoptosis are observed compared to chronic hepatitis ${ }^{25}$. 
A variant form of post transplant hepatitis $\mathrm{C}$ is a cholestatic hepatitis $\mathrm{C}$ that occurs in $<10 \%$ of patients, frequently associated with high viral load and immunosuppression. Usually it occurs within 1-6 months pos transplant and can progress to hepatic failure in 3-6 months ${ }^{27}$. This form is characterized by very high viral load, cellular ballooning, low inflammation, and a Th2 intra-hepatic immunological response. These features suggest that the liver lesion is due to a direct cytopathic injury caused by $\mathrm{HCV}^{25}$. Chronic hepatitis is established about 6-12 months post-transplantation ${ }^{25}$. With the development of chronic hepatitis, a decrease of viral load is observed, with a pattern of immune-mediated injury. The specific response to $\mathrm{HCV}$ can be detected by the pattern of Th1 response and by fibrosis stimulation. The expression of genes induced by interferon is increased as also is the expression of genes associated with apoptosis and fibrosis ${ }^{25,28}$. The best strategy for hepatitis $C$ treatment is to perform it before the transplant. However, patients with advanced cirrhosis have low tolerance to treatment. The ILTS suggests that patients with decompensate cirrhosis and MELD $<18$ should be considered for treatment ${ }^{29}$. The rate of sustained response in these groups was $20-24 \%{ }^{30}$. In transplanted patients the rate of sustained virological response using pegylated interferon and ribavirin is $12-34 \%{ }^{31}$. The survival rate of patients with $\mathrm{HCV}$ undergoing liver transplantation have increased morbidity and mortality and these patients have lower 5 and 10 year survival rates when compared to patients undergoing liver transplantation for other aetiologies of cirrhosis $^{32}$.

\section{Final considerations}

Hepatitis $C$ is the main cause of cirrhosis and hepatocellular carcinoma and the main indication of liver transplantation. The burden we are seeing today is the late consequence of infection that occurred in the past before $\mathrm{HCV}$ was identified. The identification of $\mathrm{HCV}$ allowed better control of the infection but contamination still continues to occur. The treatment of chronic HCV hepatitis is far from ideal but should always be used when possible and before transplantation. Prophylactic measures against HCV infection such as vaccines being tested. Measures for early recognition of complications of liver disease are recommended. Screening for hepatocellular carcinoma is recommended in order to improve the prognosis. Postransplantation hepatitis $\mathrm{C}$ must be recognized and treated and new therapeutic approaches are needed.

\section{References}

1. Choo QL, Kuo G, Weiner AJ, Overby LR, Bradley DW, Houghton $M$. Isolation of a cDNA clone derived from a blood-borne non-A, non-B viral hepatitis genome. Science. 1989; 244:359-62.

2. Robertson B, Myers G, Howard C, Brettin T, Bukh J, Gaschen B, Gojobori T, Maertens G, Mizokami M, Nainan O, Netesov S, Nishioka K, Shin T, Simmonds P, Smith D, Stuyver L, Weiner A. Classification, nomenclature, and database development for hepatitis $\mathrm{C}$ virus (HCV) and related viruses: proposals for standardization. International Committee on Virus Taxonomy. Arch Virol 1998; 143:2493-503.

3. Liang TJ, Rehermann B, Seeff LB, Hoofnagle JH. Pathogenesis, natural history, treatment, and prevention of hepatitis C. Ann Intern Med. 2000; 132:296-305.

4. Simmonds $P$. Variability of the hepatitis $C$ virus genome. Curr Stud Hematol Blood Transfus. 1998; 62:38-63.

5. Martell M, Esteban JI, Quer J, Genesca J, Weiner A, Esteban R, Guardia J, Gomez J. Hepatitis C virus (HCV) circulates as a population of different but closely related genomes: quasispecies nature of $\mathrm{HCV}$ genome distribution. J Virol. 1992; 66:3225-9.

6. Pawlotsky JM. Hepatitis C virus genetic variability: pathogenic and clinical implications. Clin Liver Dis. 2003; 7:45-66.

7. Focaccia R, Baraldo DC, Ferraz ML, Martinelli AL, Carrilho FJ, Goncales FL, Jr., Pedroso ML, Coelho HS, Lacerda MA, Brandao CE, Mattos AA, Lira LG, Zamin I, Jr., Pinheiro JO, Tovo CV, Both CT, Soares JA, Dittrich S. Demographic and anthropometrical analysis and genotype distribution of chronic hepatitis $\mathrm{C}$ patients treated in public and private reference centers in Brazil. Braz J Infect Dis. 2004; 8:348-55.

8. Mihm U, Herrmann E, Sarrazin C, Zeuzem S. Review article: predicting response in hepatitis $\mathrm{C}$ virus therapy. Aliment Pharmacol Ther. 2006; 23:1043-54.

9. Shepard CW, Finelli L, Alter MJ. Global epidemiology of hepatitis C virus infection. Lancet Infect Dis. 2005; 5:558-67.

10. Focaccia R, da Conceição OJ, Sette H, Jr., Sabino E, Bassit L, Nitrini DR, Lomar AV, Lorenço R, Vieira DS, Kiffer CR, Santos EB, Gonzales MP, Saez-Alquezar A, Riscal JR, Fischer D. Estimated Prevalence of Viral Hepatitis in the General Population of the Municipality of Sao Paulo, Measured by a Serologic Survey of a Stratified, Randomized and Residence-Based Population. Braz J Infect Dis. 1998; 2:269-84.

11. Valente VB, Covas DT, Passos AD. [Hepatitis B and C serologic markers in blood donors of the Ribeirão Preto Blood Center]. Rev Soc Bras Med Trop. 2005; 38:488-92.

12. Kim WR. The burden of hepatitis $\mathrm{C}$ in the United States. Hepatology. 2002; 36:30-4.

13. Strickland GT. Liver disease in Egypt: Hepatitis C superseded schistosomiasis as a result of iatrogenic and biological factors. Hepatology. 2006; 43:915-22.

14. Poynard T, Bedossa P, Opolon P. Natural history of liver fibrosis progression in patients with chronic hepatitis C. The OBSVIRC, METAVIR, CLINIVIR, and DOSVIRC groups. Lancet. 1997; 349:825-32.

15. Houghton M, Abrignani S. Prospects for a vaccine against the hepatitis C virus. Nature. 2005; 436:961-6.

16. Manns MP, McHutchison JG, Gordon SC, Rustgi VK, Shiffman M, Reindollar R, Goodman ZD, Koury K, Ling $\mathrm{M}$, Albrecht JK. Peginterferon alfa-2b plus ribavirin compared with interferon alfa-2b plus ribavirin for initial treatment of chronic hepatitis $\mathrm{C}$ : a randomised trial. 
Lancet. 2001; 358:958-65.

17. Fried MW, Shiffman ML, Reddy KR, Smith C, Marinos G, Goncales FL, Jr., Haussinger D, Diago M, Carosi G, Dhumeaux D, Craxi A, Lin A, Hoffman J, Yu J. Peginterferon alfa-2a plus ribavirin for chronic hepatitis C virus infection. N Engl J Med. 2002; 347:975-82.

18. Mazzaferro V, Regalia E, Doci R, Andreola S, Pulvirenti A, Bozzetti F, Montalto F, Ammatuna M, Morabito A, Gennari L. Liver transplantation for the treatment of small hepatocellular carcinomas in patients with cirrhosis. $\mathrm{N}$ Engl J Med. 1996; 334:693-9.

19. Bruix J, Sherman M. Management of hepatocellular carcinoma. Hepatology. 2005; 42:1208-36.

20. Kanwal F, Dulai GS, Spiegel BM, Yee HF, Gralnek IM. A comparison of liver transplantation outcomes in the prevs. post-MELD eras. Aliment Pharmacol Ther. 2005; 21:169-77.

21. Sharma P, Balan V, Hernandez JL, Harper AM, Edwards EB, Rodriguez-Luna H, Byrne T, Vargas HE, Mulligan D, Rakela J, Wiesner RH. Liver transplantation for hepatocellular carcinoma: the MELD impact. Liver Transpl. 2004; 10:36-41.

22. Everhart JE, Wei Y, Eng H, Charlton MR, Persing DH, Wiesner RH, Germer JJ, Lake JR, Zetterman RK, Hoofnagle JH. Recurrent and new hepatitis $\mathrm{C}$ virus infection after liver transplantation. Hepatology. 1999; 29:1220-6.

23. Terrault NA. Treatment of recurrent hepatitis $\mathrm{C}$ in liver transplant recipients. Clin Gastroenterol Hepatol. 2005; 3:125-31.

24. Garcia-Retortillo M, Forns X, Feliu A, Moitinho E, Costa J, Navasa M, Rimola A, Rodes J. Hepatitis C virus kinetics during and immediately after liver transplantation. Hepatology. 2002; 35:680-7.
25. McCaughan GW, ZekryA. Mechanisms of HCV reinfection and allograft damage after liver transplantation. J Hepatol. 2004; 40:368-74.

26. Guerrero RB, Batts KP, Burgart LJ, Barrett SL, Germer JJ, Poterucha JJ, Wiesner RH, Charlton MR, Persing DH. Early detection of hepatitis $\mathrm{C}$ allograft reinfection after orthotopic liver transplantation: a molecular and histologic study. Mod Pathol. 2000; 13:229-37.

27. Lim HL, Lau GK, Davis GL, Dolson DJ, Lau JY. Cholestatic hepatitis leading to hepatic failure in a patient with organtransmitted hepatitis $\mathrm{C}$ virus infection. Gastroenterology. 1994; 106:248-51.

28. Smith MW, Walters KA, Korth MJ, Fitzgibbon M, Proll S, Thompson JC, Yeh MM, Shuhart MC, Furlong JC, Cox PP, Thomas DL, Phillips JD, Kushner JP, Fausto N, Carithers RL, Jr., Katze MG. Gene expression patterns that correlate with hepatitis $\mathrm{C}$ and early progression to fibrosis in liver transplant recipients. Gastroenterology. 2006; 130:179-87.

29. Wiesner RH, Sorrell M, Villamil F. Report of the first International Liver Transplantation Society expert panel consensus conference on liver transplantation and hepatitis C. Liver Transpl. 2003; 9:1-9.

30. Forns X, Garcia-Retortillo M, Serrano T, Feliu A, Suarez F, de la MM, Garcia-Valdecasas JC, Navasa M, Rimola A, Rodes J. Antiviral therapy of patients with decompensated cirrhosis to prevent recurrence of hepatitis $\mathrm{C}$ after liver transplantation. J Hepatol. 2003; 39:389-96.

31. Chalasani N, Manzarbeitia C, Ferenci P, Vogel W, Fontana RJ, Voigt M, Riely C, Martin P, Teperman L, Jiao J, LopezTalavera JC. Peginterferon alfa-2a for hepatitis $\mathrm{C}$ after liver transplantation: two randomized, controlled trials. Hepatology. 2005; 41:289-98.

32. Brown RS. Hepatitis $C$ and liver transplantation. Nature. 2005; 436:973-8.
Correspondence:

Dra. Ana L. C. Martinelli

School of Medicine of Ribeirão Preto

Department of Medicine

Av. Bandeirantes, 3900

14049-900 Ribeirão Preto - SP Brazil

adlcmarti@fmrp.usp.br
Conflict of interest: none Financial source: CNPq and FAPESP

\section{How to cite this article:}

Martinelli ALC; Teixeira AC; Souza FF; Sankarankutty AK; Castro e Silva O. Hepatitis C: A challenge to hepatologists and to the liver transplantation team. Acta Cir Bras. [serial on the Internet] 2006;21 Suppl 1. Available from URL: http://www.scielo.br/acb 